Problems of World Agriculture volume 18 (XXXIII), number 4, 2018: 259-269 DOI: 10.22630/PRS.2018.18.4.116

\author{
Tomasz Klusek ${ }^{1}$ \\ Warsaw University of Life Sciences - SGGW, Poland
}

\title{
Out-of-Market Agricultural Property Trading in Poland
}

\begin{abstract}
Synopsis. In the category of land property, the Civil Code specifies agricultural property. Similarly to other real property, they can be traded in the form of transfer of the ownership title, which occurs on commercial terms or with such terms excluded. In this study, out-of-market transactions with agricultural property. On the basis of the available data, changes in the figures, structure and regional differentiation of such transactions were presented. Attention was also paid to why such changes occurred.
\end{abstract}

Key words: real property market, agricultural property, out-of-market transactions

JEL Classification: K25, Q18, R39

\section{Introduction}

In the category of land property, the Civil $\operatorname{Code}^{2}$ lists agricultural property (agricultural land), which is or may be used to conduct agricultural production. They are a part of land area being a separate object of ownership, separated from surrounding land by delineation of external borders.

The notion of agricultural property in various legal regulations is not uniform: as a result, it is unclear. Lack of cohesion in this respect can even be found in the same branches of the law. From a legal standpoint, it results in a significant problem in differentiation between agricultural and non-agricultural property, which is directly reflected in the fulfilment of principle of reliable trading (Skoczylas, 2004).

Agricultural property, similarly to other real property, have specific functions and may fulfil various individual and collective needs. The specific features of that type of real property result in a specific nature of its market although it behaves just like other markets in terms of fundamental issues concerning the mechanisms of market operation. Similarly to other generic markets, it is constantly subject to changes, the intensity and directions of which depend on a range of factors. In general, they can be classified into the necessary ones, required for market to function, and the facilitating ones, which support the development of market (Belniak, 2001).

The scale and structure of agricultural property trading depend on such aspects as supply-related conditions. In this light, agricultural land prices, growing dynamically since Poland joined the European Union, can be seen as a factor facilitating supply as they supported land owners who did not conduct agricultural production in making decisions on getting rid of at least a part of their immovable production property (Rynek..., 2011). In turn, one of the factors that had a significant effect on supply-related limitations on the

${ }^{1} \mathrm{PhD}$, Department of Agricultural Economics and International Economic Relations, Faculty of Economic Sciences WULS-SGGW, Nowoursynowska 166 St., 02-787 Warszawa, e-mail: tomasz_klusek@sggw.pl, https://orcid.org/0000-0001-7304-2760

${ }^{2}$ Act of 23 April 1964 - Civil Code (consolidated text: Journal of Laws of 2018, item 1025) 
market under analysis is intensified conversion of agricultural land to other purposes. It was related, for instance, with the development of infrastructure in rural areas, construction of communication routes and urbanisation processes in impact areas of large urban agglomerations (Rynek..., 2016).

After Poland joined the European Union, along with socioeconomic development, agricultural land area started to decrease dynamically, by 49 thousand ha per year on average. The land in question covered $61.43 \%$ of the general area of the country in 2004 but in 2016 the area diminished to 59.55\%. According to the Head Office of Land Surveying and Cartography, 586 thousand ha of land were lost in total in the period from 2004 to 2016 (Ochrona..., 2016). It only partially resulted from formal exclusions for nonagricultural purposes and forestation.

Many different economic areas compete for agricultural land. Therefore, it is necessary to manage that limited resource reasonably (Marks-Bielska, 2010). It is mostly about using it to stimulate structural transformation in the Polish agriculture, which is connected for instance with improvement in the area structure of farms. Changes in this respect result from intensification and forms of agricultural property trading.

The study analysed out-of-market trading and it aims to determine the scale of that phenomenon, taking into consideration the number and structure of transactions made nationwide and in individual voivodships. For the purposes of said analyses, notarial reporting data published by the Institute of Urban Development and reports of the Institute of Agricultural and Food Economics were used in particular. The time interval covers the period from 2004 to 2017 and the starting year is not chosen at random. This is so as the year of 2004, associated most frequently with Poland joining the European Union, at the same time marks the beginning of one of the key stages of development of the Polish real property market, which also applies to the agricultural property market.

\section{Out-of-market transactions with agricultural property on the Polish real property market}

The basic rights of the owner are for instance the right to disposition of the real property, understood as the right to disposal of property, which can occur by way of its transfer (Nowak, Skotarczak, 2013). The transfer of the ownership title is the main aim standing behind the functioning of the real property trading subsystem, which is one of the key parts of the real property market system (Bryx, 2006). The subsystem covers mutual relationships between the entities participating in the transfer of rights to real property. Those are first and foremost parties to concluded contracts, i.e. sellers (former owners) and buyers (new owners). According to the provisions of the Polish law, such contracts must be drafted in the form of notarial deed or else will be null and void. The requirement for maintaining such a form results from care of the legislator for the safety of real property trading.

Ownership is a right granting its holder the fullest power over given real property. Nevertheless, it is not an absolute right, but a relatively full right in most contemporary legal systems. In Poland, the borders of the ownership title are delineated by three factors: provisions of the statutory law, principles of community life and the socioeconomic purpose of that title (Strzelczyk, 2010). The first of the limitations is to be understood as the entire statutory law, i.e. statutes stemming from various branches of the law. An example 
can be the provisions of the Act on spatial planning and development ${ }^{3}$, under which local land use plans interfering in the ownership title to real property located in areas where those plans are effective are enacted (Kopyra, 2009).

The real property market in Poland is characterised by a wide scope in which the state can intervene. Such intervention can assume various forms and is above all implemented by way of establishing legal principles of how this market operates. They pertain for instance to the change of the owner of agricultural property owned by the State Treasury or in exchange for pension and disability pension benefits. However, special conditions of trading with such real property result first and foremost from regulations on the shaping of agricultural system (Marciniuk, 2015).

Notarial reporting data indicate that transformations in the agricultural property ownership structure in Poland in the period under study, i.e. between 2004 and 2017, resulted from sale and purchase transactions, or market transactions, in the first place. The vast majority of such transactions were made by private entities (Klusek, 2017), which was to be directly associated with their dominance in the agricultural land ownership structure across the country and in individual voivodships (Jędruchniewicz, Maśniak, 2018). Similarly to previous years, intensification of trading in agricultural property in the form of purchase and sale transactions differed depending on area. Relatively speaking, most such transactions were made in the Lubelskie Voivodship and the Mazowieckie Voivodship. The fewest transactions were made in the Lubuskie Voivodship and the Opolskie Voivodship.

Persistent regional differences in the intensification of the market trading must be associated both with spatial differences in agricultural markets and with a differentiated level of urbanisation in rural areas (Rynek..., 2016). When interpreting regional differences in terms of agricultural land trading, what needs to be taken into account as well is the effect of the activity of the Agricultural Property Agency. As a legal person being a fiduciary of the State Treasury, that institution was very significant for the Polish agriculture due to, for instance, its effect on the formation and expansion of farms (MarksBielska, Kisiel, 2013). This pertains for example to the Warmińsko-Mazurskie Voivodship, which belongs to the group of voivodships where the resource of land from the former state sector was the most extensive (Kisiel, Marks-Bielska, 2012).

In addition to information on market transactions, where sale occurs by way of equivalent exchange, notarial reporting, being the basis for analysis of trading on the real property market, also contains information on out-of-market transactions, where change of the owner occurs without any monetary equivalent (Kałkowski, 2003). In the case of agricultural property, such transactions are most often acquisitions within a family, including family inheritance divisions, donations and inheritances and life estate contracts. What supplements such transactions are contracts of real property sale in exchange for social insurance benefits.

Analysis of the available data shows that, in dynamic terms, there was a drop in the share of over-the-transactions in the overall number of agricultural property transactions. In 1990 , i.e. at the beginning of the Polish political transformation, the share in question was at over 70\%; in 1994 it was 59\% and in $2004-51 \%$ (Klusek, 2017). After 2005, market transactions started to dominate in the structure of contracts concerning the transfer of ownership title to agricultural property. Between 2004 and 2015, national out-of-market

${ }^{3}$ Act of 27 March 2007 on spatial planning and development (consolidated text: Journal of Laws of 2017, item 1073) 
transactions constituted ca. $45 \%$ of all agricultural property transactions (Table 1). Most transactions of that sort were made, as always, in the Mazowieckie Voivodship, the Lubelskie Voivodship and the Podkarpackie Voivodship and the fewest - in the Lubuskie Voivodship, the Opolskie Voivodship and the Zachodniopomorskie Voivodship (Table 2).

Table 1. Share of agricultural property transactions in real property transactions made between 2004 and 2017 (notarial deeds)

\begin{tabular}{|c|c|c|c|c|c|c|c|c|c|}
\hline \multirow{4}{*}{ Years } & \multirow{2}{*}{\multicolumn{3}{|c|}{ Real property transactions }} & \multicolumn{6}{|c|}{ Including } \\
\hline & & & & \multirow{3}{*}{ in total } & \multirow{2}{*}{\multicolumn{2}{|c|}{$\begin{array}{l}\text { transactions } \\
\text { pertaining to } \\
\text { agricultural } \\
\text { property }\end{array}$}} & \multirow{3}{*}{ in total } & \multirow{2}{*}{\multicolumn{2}{|c|}{$\begin{array}{l}\text { transactions pertaining } \\
\text { to agricultural property }\end{array}$}} \\
\hline & \multirow[t]{2}{*}{ in total } & \multicolumn{2}{|c|}{$\begin{array}{c}\text { including } \\
\text { transactions } \\
\text { pertaining to } \\
\text { agricultural property }\end{array}$} & & & & & & \\
\hline & & number & $\%$ & & number & $\%$ & & number & $\%$ \\
\hline 2004 & 629323 & 163956 & 26,0 & 440779 & 80271 & 18,2 & 188544 & 83685 & 44,4 \\
\hline 2005 & 594862 & 155511 & 26,1 & 425532 & 76450 & 18,0 & 169330 & 79061 & 46,7 \\
\hline 2006 & 648365 & 154174 & 23,8 & 490870 & 84059 & 17,1 & 157495 & 70115 & 44,5 \\
\hline 2007 & 716114 & 162959 & 22,8 & 489797 & 95624 & 19,5 & 226317 & 67335 & 29,7 \\
\hline 2008 & 719974 & 168330 & 23,4 & 471451 & 90447 & 19,2 & 248523 & 77883 & 31,3 \\
\hline 2009 & 642889 & 146745 & 22,8 & 409835 & 79147 & 19,3 & 233054 & 67598 & 29,0 \\
\hline 2010 & 676139 & 148208 & 21,9 & 451573 & 82654 & 18,3 & 224566 & 65554 & 29,2 \\
\hline 2011 & 680064 & 160824 & 23,6 & 451723 & 88867 & 19,7 & 228341 & 71957 & 31,5 \\
\hline 2012 & 644960 & 151789 & 23,5 & 428288 & 88359 & 20,6 & 216672 & 63430 & 29,3 \\
\hline 2013 & 677856 & 152830 & 22,5 & 461895 & 91082 & 19,7 & 215961 & 61748 & 28,6 \\
\hline 2014 & 679047 & 145907 & 21.5 & 462994 & 84423 & 18,2 & 216053 & 61484 & 28,4 \\
\hline 2015 & 719721 & 162587 & 22,6 & 486891 & 92757 & 19,1 & 232830 & 69830 & 30,0 \\
\hline 2016 & 731556 & 145178 & 19,8 & 488593 & 69788 & 14,3 & 242963 & 75390 & 31,0 \\
\hline 2017 & 717097 & 122111 & 17,0 & 489342 & 57051 & 11,7 & 227755 & 65060 & 28,6 \\
\hline
\end{tabular}

Source: (Kałkowski 2012, Kałkowski 2015, Ministerstwo Sprawiedliwości), own calculations.

Bearing in mind the latest data on agricultural property trading, it needs to be stressed that in 2016, as purchase and sale transactions dropped in number, there was more trading in out-of-market forms. Notary's offices reported ca. 75.4 thousand such contracts, which means a growth by $8 \%$ compared to the previous year (Table 1). The observed growth in the share of out-of-market trading in agricultural land ownership changes in Poland is to be linked with a change in the principles of operation of agricultural land markets, which results from the enactment of the Act of 14 April 2016 on suspension of sale of real property in the Agricultural Property Stock of the State Treasury and on amendment to some statues ${ }^{4}$. Even though the new principles of agricultural land trading introduced with the said act came into force in the second quarter of 2016, their effect on the scale of transactions made could even be seen earlier. This resulted from the fact that the people who planned to transfer ownership titles both in the market and out-of-market trading strived to finalise their intentions even before the act entered into force (Rynek..., 2017).

${ }^{4}$ Journal of Laws of 2016, item 565, as amended) 
Increase in the merit of out-of-market transactions in agricultural land trading, showing in the recent years, may have an effect of slowing down the process of agricultural land concentration in the Polish agriculture. This is so as studies conducted by the Institute of Agricultural and Food Economics show that these changes are facilitated first and foremost by market trading (Rynek..., 2017). Areas with many family acquisitions are characterised by considerable fragmentation in land use while in areas where market transactions dominate the concentration processes are much more advanced (Rynek..., 2015).

The fragmentation of the area structure is not beneficial from the economic point of view for instance: it contributes to squandering some potential of the production capacity of agriculture and to increased production costs. Excessive fragmentation limits the profitability of agriculture and weakens its market orientation; it also facilitates decapitalisation of fixed assets on farms (Dacko, Dacko, 2012).

Table 2. Out-of-market agricultural property transactions by voivodship - comparative analysis for years from 1994 to 2003 and from 2004 to 2013 (cumulative data)

\begin{tabular}{|c|c|c|c|c|c|c|}
\hline \multirow[t]{2}{*}{ Voivodship } & \multicolumn{2}{|c|}{$\begin{array}{c}\text { Number of out-of-market } \\
\text { agricultural property } \\
\text { transactions }\end{array}$} & \multicolumn{2}{|c|}{$\begin{array}{l}\text { Share of out-of-market } \\
\text { agricultural property } \\
\text { transactions in all } \\
\text { agricultural property } \\
\text { transactions }(\%)\end{array}$} & \multicolumn{2}{|c|}{$\begin{array}{l}\text { Structure of out-of-market } \\
\text { agricultural property } \\
\text { transactions (Poland }=100 \text { ) }\end{array}$} \\
\hline & 1994-2003 & 2004-2013 & 1994-2003 & $2004-2013$ & 1994-2003 & $2004-2013$ \\
\hline Dolnośląskie & 31346 & 23859 & 36,7 & 34,5 & 3,4 & 3,7 \\
\hline Kujawsko-pomorskie & 32212 & 28097 & 39,0 & 39,1 & 3,5 & 4,0 \\
\hline Lubelskie & 128041 & 96096 & 49,6 & 46,1 & 14,1 & 13,6 \\
\hline Lubuskie & 8243 & 7767 & 28,7 & 24,4 & 0,9 & 1,1 \\
\hline Łódzkie & 68896 & 52854 & 55,8 & 48,0 & 7,6 & 7,5 \\
\hline Małopolskie & 106319 & 77301 & 68,6 & 54,0 & 11,7 & 10,9 \\
\hline Mazowieckie & 137323 & 102338 & 53,6 & 48,4 & 15,1 & 14,4 \\
\hline Opolskie & 19430 & 16183 & 40,8 & 36,4 & 2,1 & 2,3 \\
\hline Podkarpackie & 106010 & 85746 & 63,7 & 54,8 & 11,7 & 12,1 \\
\hline Podlaskie & 53882 & 41611 & 49,8 & 49,4 & 5,9 & 5,9 \\
\hline Pomorskie & 20613 & 19413 & 33,7 & 33,4 & 2,3 & 2,7 \\
\hline Śląskie & 46785 & 24640 & 67,5 & 51,3 & 5,2 & 3,5 \\
\hline Świętokrzyskie & 55617 & 54069 & 59,6 & 54,1 & 6,1 & 7,6 \\
\hline Warmińsko-mazurskie & 24706 & 17326 & 33,9 & 28,5 & 2,7 & 2,4 \\
\hline Wielkopolskie & 52176 & 44748 & 43,6 & 42,2 & 5,7 & 6,3 \\
\hline Zachodniopomorskie & 18259 & 16264 & 28,5 & 26,5 & 2,0 & 2,3 \\
\hline Total & 909858 & 708312 & 50,6 & 45,3 & 100,0 & 100,0 \\
\hline
\end{tabular}

Źródło: (Kałkowski 2012, Kałkowski 2015), own calculations.

In the case of spatial range, the agricultural property market is most of all a local market, which is mostly influenced by the basic physical feature of real property, i.e. 
immovability. The local nature of the market results in the fact that it is sensitive to local demographic, economic and social factors. Therefore, the size and shape of real property market is influenced by the population in a given area, employment rate, size of existing resource or land availability or land price. These factors result in the fact that market activity levels in different regions may vary significantly. This also applies to out-of-market agricultural property transactions.

The data presented in Table 2 show differences among individual voivodships in terms of share of such transactions in all transactions. It needs to be stressed that out-of-market transactions invariably dominate in areas with strongly cultivated traditional approach to farms, i.e. where they are seen mostly as family property and where they fulfil residential functions for the most part (Kowalski, 2015). This applies mostly to areas located in the Małopolskie Voivodship, the Świętokrzyskie Voivodship and the Podkarpackie Voivodship, where the area structure is characterised by intense fragmentation and a considerable part of farms do not fulfil significant profit-earning functions.

\section{Structure of out-of-market agricultural property transactions}

Due to the family-oriented nature of individual farms, out-of-market agricultural land trading plays a very significant role in the shaping of structural transformations in the Polish agriculture. In effect, a large part of land is taken over by successive generations. The data presented in Table 3 show that this is most often done by donations. Donations have been dominating since the 1990s. In 2017, they were on average at a level of over $79 \%$ of all out-of-market transfers of ownership titles to agricultural land.

A donation contract is classified as one of the so-called derivate manners of acquiring ownership title (Kisilowska, 2006), where the new owner, as the successor, derives its rights from the rights of their predecessor. For the contract to be consummated, both parties, i.e. the donor and the donee, must submit their declarations of will (Strzelczyk, 2010). A significant feature of donation is that it is free, which means that the donor does not receive any equivalent, neither at the time of transferring a gift nor at any time in the future (Brzeszczyńska, 2002).

Among the specified forms of over-the-market agricultural land trading, the second place in the recent years has been taken by inheritance divisions and co-ownership dissolutions. Such contracts are regarded as particular difficulty for acceleration of land concentration in individual agriculture. Therefore, each reduction in their share is seen as rationalisation in the out-of-market agricultural land trading (Rynek..., 2011).

Similarly to other European countries, the Polish legislation provides that when the owner dies, the farm passes to their successors. Property succession results from the will or is conducted on general terms of the inheritance law (Dudek, 2016).

The relatively smallest part of the out-of-market agricultural land trading are life estate contracts. Their share in the overall number of contracts concerning out-of-market transfer of ownership title to agricultural land registered in 2017 was merely $2.3 \%$, i.e. it was at a level similar to the previous years. In these instances, parties to contracts are most often relatives and the contracts consist in the real property owner transferring its ownership title to another person in exchange for guarantee of maintenance for life (Strzelczyk, 2010). Life estate is a property right of a strictly private nature; it is not alienable, is not subject to succession and it expires upon the death of the right holder (Czajkowska-Matosiuk 2013). 
Table 3. Structure of out-of-market agricultural property transactions between 2004 and 2017 (notarial deeds)

\begin{tabular}{|c|c|c|c|c|c|c|c|c|c|}
\hline \multirow{3}{*}{ Years } & \multirow{3}{*}{$\begin{array}{l}\text { Out-of- } \\
\text { market } \\
\text { transactions } \\
\text { in total }\end{array}$} & \multicolumn{8}{|c|}{ Including } \\
\hline & & \multicolumn{2}{|c|}{ donations } & \multicolumn{2}{|c|}{$\begin{array}{l}\text { inheritance } \\
\text { divisions and co- } \\
\text { ownership } \\
\text { dissolutions }\end{array}$} & \multicolumn{2}{|c|}{$\begin{array}{l}\text { life estate } \\
\text { contracts }\end{array}$} & \multicolumn{2}{|c|}{$\begin{array}{l}\text { real property sale } \\
\text { contracts for social } \\
\text { insurance benefits }\end{array}$} \\
\hline & & number & $\%$ & number & $\%$ & number & $\%$ & number & $\%$ \\
\hline 2004 & 83685 & 60034 & 71,7 & 6404 & 7,6 & 2268 & 2,7 & 14979 & 17,9 \\
\hline 2005 & 79061 & 58019 & 73,4 & 5264 & 6,6 & 2619 & 3,3 & 12976 & 16,4 \\
\hline 2006 & 70115 & 51866 & 74,0 & 5294 & 7,5 & 2514 & 3,6 & 10471 & 14,9 \\
\hline 2007 & 67335 & 54877 & 81,5 & 5070 & 7,5 & 1409 & 2,1 & 5979 & 8,9 \\
\hline 2008 & 77883 & 61736 & 79,3 & 5661 & 7,3 & 1901 & 2,4 & 8576 & 11,0 \\
\hline 2009 & 67598 & 55728 & 82,4 & 5524 & 8,2 & 1926 & 2,4 & 4720 & 7,0 \\
\hline 2010 & 65554 & 54079 & 82,5 & 5220 & 8,0 & 1707 & 2,6 & 4548 & 6,0 \\
\hline 2011 & 71957 & 56815 & 78.9 & 5098 & 7,1 & 2237 & 3,1 & 7807 & 10,8 \\
\hline 2012 & 63430 & 50132 & 79,0 & 5132 & 8,1 & 1946 & 3,1 & 6220 & 9,8 \\
\hline 2013 & 61748 & 46351 & 75,1 & 8316 & 13,5 & 2061 & 3,3 & 5020 & 8,1 \\
\hline 2014 & 61484 & 46868 & 76,2 & 7615 & 12,4 & 2202 & 3,6 & 4799 & 7,8 \\
\hline 2015 & 69830 & 53943 & 77,2 & 8159 & 11,7 & 2920 & 4,2 & 4808 & 6,9 \\
\hline 2016 & 75390 & 61261 & 81,2 & 8137 & 10,8 & 1781 & 2,4 & 4211 & 5,6 \\
\hline 2017 & 65060 & 51738 & 79,5 & 7149 & 11,0 & 1465 & 2,3 & 4708 & 7,2 \\
\hline
\end{tabular}

Źródło: (Kałkowski 2012, Kałkowski 2015, Ministerstwo Sprawiedliwości), own calculations.

In general, in 2017 family acquisitions constituted 93\% of the out-of-market agricultural land trading. The remaining $7 \%$ pertained to the situations where owned land was taken over by the State Treasury in exchange for pension and disability pension benefits. The number of such instances in the last decade halved.

The Polish pension-related legislation provides for when and on what terms farmers can end their professional activity in exchange for pension and disability pension benefits. Between 1990 and 2012, agricultural pension was granted to the insured party who attained the retirement age (60 years of age for women and 65 years of age for men) and had been subject to pension and disability pension insurance for at least 25 years. It was also possible to retire earlier ( 5 years before achievement of the retirement age) provided that the period of insurance had been longer (by 5 years) and the agricultural activity was discontinued. If a farmer discontinued their professional activity as a result of unfitness for work due to physical fitness loss, he was granted agricultural disability pension. In 2013, social insurance regulations were changed. As a result, the retirement age was extended and rendered the same for women and men (Dudek, 2016).

A range of conditions influences the scale of agricultural land trading and its structure; a significant role in this respect is played by economic factors. It is not only about the economic situation of agriculture, but also about transformations occurring in the entire national economy. Economic conditions changed fundamentally when Poland joined the 
European Union and the Polish national agricultural sector was covered by the instruments of the Common Agricultural Policy.

Table 4. Structure of out-of-market agricultural property transactions by voivodship (cumulative data for the period from 2004 to 2013)

\begin{tabular}{|c|c|c|c|c|c|c|c|c|c|}
\hline \multirow{3}{*}{ Voivodship } & \multirow{3}{*}{$\begin{array}{l}\text { Out-of- } \\
\text { market } \\
\text { transactions } \\
\text { in total }\end{array}$} & \multicolumn{8}{|c|}{ Including } \\
\hline & & \multicolumn{2}{|c|}{ donations } & \multicolumn{2}{|c|}{$\begin{array}{l}\text { inheritance } \\
\text { divisions and co- } \\
\text { ownership } \\
\text { dissolutions }\end{array}$} & \multicolumn{2}{|c|}{$\begin{array}{l}\text { life estate } \\
\text { contracts }\end{array}$} & \multicolumn{2}{|c|}{$\begin{array}{l}\text { real property sale } \\
\text { contracts for social } \\
\text { insurance benefits }\end{array}$} \\
\hline & & number & $\%$ & number & $\%$ & number & $\%$ & number & $\%$ \\
\hline Dolnośląskie & 23859 & 19682 & 82,5 & 1420 & 5,9 & 471 & 2,0 & 2286 & $\overline{9,6}$ \\
\hline $\begin{array}{l}\text { Kujawsko- } \\
\text { pomorskie }\end{array}$ & 28097 & 19812 & 70,5 & 1595 & 5,7 & 952 & 3,4 & 5738 & 20,4 \\
\hline Lubelskie & 96096 & 75918 & 79.0 & 8936 & 9,3 & 864 & 0,9 & 10378 & 10,8 \\
\hline Lubuskie & 7767 & 6784 & 87,3 & 334 & 4,3 & 157 & 2,0 & 492 & 6,4 \\
\hline Łódzkie & 52854 & 39161 & 74,1 & 3649 & 6,9 & 1801 & 3,4 & 8243 & 15,6 \\
\hline Małopolskie & 77301 & 56606 & 73,2 & 8200 & 10,6 & 4386 & 5,7 & 8109 & 10,5 \\
\hline Mazowieckie & 102338 & 79381 & 77,6 & 8381 & 8,2 & 2348 & 2,3 & 12228 & 11,9 \\
\hline Opolskie & 16183 & 11769 & 72,7 & 1485 & 9,2 & 607 & 3,8 & 2322 & 14,3 \\
\hline Podkarpackie & 85746 & 72054 & 84,0 & 6895 & 8,0 & 2132 & 2,5 & 4665 & 5,5 \\
\hline Podlaskie & 41611 & 30416 & 73,1 & 2234 & 5,4 & 2374 & 5,7 & 6587 & 15,8 \\
\hline Pomorskie & 19413 & 15351 & 79,1 & 1213 & 6,3 & 551 & 2,8 & 2298 & 11,8 \\
\hline Śląskie & 24640 & 19936 & 80,9 & 2522 & 10,3 & 650 & 2,6 & 1532 & 6,2 \\
\hline Świętokrzyskie & 54069 & 43390 & 80,2 & 5433 & 10,1 & 744 & 1,4 & 4502 & 8,3 \\
\hline $\begin{array}{l}\text { Warmińsko- } \\
\text { mazurskie }\end{array}$ & 17326 & 14177 & 81,8 & 988 & 5,7 & 239 & 1,4 & 1922 & 11,1 \\
\hline Wielkopolskie & 44748 & 31486 & 70,4 & 2575 & 5,8 & 1801 & 4,0 & 8886 & 19,8 \\
\hline $\begin{array}{l}\text { Zachodniopom } \\
\text { orskie }\end{array}$ & 16264 & 13706 & 84,3 & 1212 & 7,4 & 238 & 1,5 & 1108 & 6,8 \\
\hline Total & 708312 & 549629 & 77,6 & 57090 & 8,0 & 20297 & 2,9 & 81296 & 11,5 \\
\hline
\end{tabular}

Źródło: (Kałkowski 2012, Kałkowski 2015), own calculations.

After 2004, agricultural land prices went up quickly both on the state market (land of the Agricultural Property Stock of the State Treasury) and the private market. Their dynamics between 2004 and 2014 was $487.1 \%$ on the private market and $546.6 \%$ on the state market (Marks-Bielska, 2016). As prices increased, agricultural property became one of the most attractive forms of capital deposit and, in addition to agricultural producers, other entities also decided to purchase them. This strengthened the intensification of the increase trend, which occurred not only in the case of the land most valuable from the viewpoint of production, but also in the case of land of low agricultural merit. It can be implied that a part of made transactions were purely speculative and was related to intention to use the purchased land for non-agricultural purposes. 
Comparison of spatial differentiation in price levels shows that the factors which had an effect on them were for instance the level of farming culture in a given area, density of high-producing units and the so-called location rent. The highest prices were achieved by land located on areas traditionally standing out with high agricultural advancement and considerable share of large commercial farms. This applies first and foremost to the Wielkopolskie Voivodship and the Kujawsko-Pomorskie Voivodship, where agricultural land were in 2011 by 50\% more expensive compared to the national average and the price of land of high agricultural merit was nearly twice the average price (Rynek..., 2012). It needs to be pointed out here that since 2006 a tendency to reduce territorial differences in agricultural land price levels has started to show gradually, which is indicated by a drop in the coefficient of variation. In 2013, the coefficient was at the level of ca. $25 \%$, which means that it decreased by 10 percentage points by 2006 (Rynek..., 2014).

The intensity and forms of agricultural land trading are also strongly influenced by the institutional system, particularly legal standards reflecting the agricultural policy of the state. One of the fundamental legal acts regulating the issues of ownership title to agricultural property in Poland is particularly the Act of 11 April 2003 on the shaping of agricultural system ${ }^{5}$, amended many times. Its last considerable amendment, under the abovementioned Act of 14 April 2016, included introduction of various limitations on agricultural property trading. They covered e.g. general subjective and objective limitations concerning the acquisition of such real property, the requirement that acquirers of farms keep them and a wide application of the right of first refusal and the right of acquisition also in the case of disposal of shares of companies owning agricultural property (Szymczyk, 2017).

Moreover, changes in regulations introduced by the Act of 14 April 2016 resulted in a change in priorities of the policy concerning the development of the Agricultural Property Stock of the State Treasury by shift of centre of gravity from land sale to land lease. In effect, in 2016 the area of land leased to farmers was nearly 60 thousand ha compared to 37.3 thousand ha in 2015 . It is a growth by over $160 \%$. At the same time, ca. 18 thousand ha was sold in 2016 , which is merely $23 \%$ as compared to the sale figures of 2015 . Plans covering the period up to 2019 have assumed further decreases in sale down to the level of slightly above 9 thousand ha per year (Biuletyn..., 2017).

It goes without doubt that agricultural property trading should be rationed due to the necessity to shape the agrarian structure of the Polish agriculture. There is a doubt, however, that the current legal solutions in this respect lead to excessive interference of the state in property and production interests of entities participating in the trading and that it paves way to excessive limitation of the ownership title (Mikołajczyk, 2016). In this light, there is real threat that excessive rationing will slow down the process of strengthening family farms, occurring over the recent years and consisting in successive increase in their average area (Marciniuk, 2016).

\section{Summary}

Apart from agricultural land trading on market, changes in use of agricultural land result from transfer of ownership title on out-of-market terms. Most frequently, these are

\footnotetext{
${ }^{5}$ consolidated text: Journal of Laws of 2018, item 1405.
} 
acquisitions within a family, covering donations, inheritance divisions and life estate contracts. These forms, based on traditions, affect the agrarian structure by slowing down land concentration and even contributing to further land fragmentation. In this context, what may evoke some doubts is a dominance of out-of-market transactions over market ones along with a decrease in the number of all performed transactions, showing after 2015.

The scale of out-of-market agricultural land trading is diversified spatially. It needs to be underlined here that in areas of fragmented agrarian structure, various forms of that trading have a much wider range compared to areas grouping farms well equipped with production assets and having relatively high economic power. Local markets are unique markets where specific economic and social relations form. It is about supply, demand, prices and all relations occurring between all players of these markets.

\section{References}

Belniak, S. (2001). Rozwój rynku nieruchomości w Polsce na tle krajów wysoko rozwiniętych (The Development of the Real Estate Market Against the Background of Highly Developed Countries). Wydawnictwo Akademii Ekonomicznej w Krakowie, Kraków.

Biuletyn Informacyjny nr 6 (Information Bulletin N N $^{\circ}$ ). MRiRW, Warszawa 2017.

Bryx, M. (2006). Rynek nieruchomości. System i funkcjonowanie (Real Estate Market. System and Operation). Poltext, Warszawa.

Brzeszczyńska, S. (2002). Nieruchomość w firmie (Real Estate in a Company). Wydawnictwo C.H. Beck, Warszawa.

Czajkowska-Matosiuk, K. (2013). Prawo cywilne (Civil Law). Wydawnictwo C.H. Beck, Warszawa.

Dacko M., Dacko A. (2012). Struktura agrarna rolnictwa w województwie małopolskim (The Agrarian Structure in the Małopolskie Voivodship). Roczniki Naukowe SERiA, 14(3), 53-58.

Dudek, M. (2016). Sukcesja indywidualnych gospodarstw rolnych jako czynnik przeobrażeń strukturalnych w polskim rolnictwie (Inheriting of Private Farms as a Factor of Structural Changes in Polish Agriculture). Studia i Monografie nr 170. IERiGŻ-PIB, Warszawa.

Jędruchniewicz, A., Maśniak, J. (2018). Przemiany własnościowe ziemi rolnej w Polsce (Changes in Agricultural Land Ownership in Poland). ZN SGGW Ekonomika i Organizacja Gospodarki Żywnościowej 121, 25-39.

Kałkowski, L. (red.) (2003). Rynek nieruchomości w Polsce (Real Estate Market in Poland). Twigger, Warszawa.

Kałkowski, L. (red.) (2012). 22 lata polskiego rynku nieruchomości: monitoring za lata 1990-2011 (22 Years of Polish Real Estate Market: Monitoring for 1990-2011). Instytut Rozwoju Miast, Kraków.

Kałkowski, L. (red.) (2015). 25 lat polskiego rynku nieruchomości: monitoring za lata 1990-2014 (25 Years of Polish Real Estate Market: Monitoring for 1990-2014). Instytut Rozwoju Miast, Kraków.

Kisiel, R., Marks-Bielska, R. (red.) (2012). Przemiany w rolnictwie i na obszarach wiejskich z udziałem Agencji Nieruchomości Rolnych na przykładzie województwa warmińsko-mazurskiego (Changes in Agriculture and Rural Areas in which the Agency of Agricultural Real Estates is Involved: a Case Study Covering the Province of Warmia and Mazury). Wydawnictwo Uniwersytetu Warmińsko-Mazurskiego w Olsztynie, Olsztyn.

Kisilowska, H. (red.) (2006). Nieruchomości. Wzory pism i umów (Real Estates. Templates for Written Documents). LexisNexis, Warszawa.

Klusek, T. (2017). Rozmiary i regionalne zróżnicowanie polskiego rynku nieruchomości (Size and Regional Differences in the Polish Agricultural Property Market). ZN SGGW Ekonomika i Organizacja Gospodarki Żywnościowej, 119, 101-117.

Kopyra, J. (red.) (2009). Prawo nieruchomości (Real Estate Law). Poltext, Warszawa.

Kowalski, A. (red.) (2015). Analiza produkcyjno-ekonomicznej sytuacji rolnictwa i gospodarki żywnościowej w 2014 roku (Analysis of Production and Economic Situation of Agriculture and Food Industry in 2014). IERiGŻ-PIB, Warszawa.

Kucharska-Stasiak, E. (2006). Nieruchomość w gospodarce rynkowej (Real Estates in Market Economy). Wydawnictwo Naukowe PWN, Warszawa.

Marciniuk, K. (2015). Rodzinne gospodarstwo rolne w procesie obrotu nieruchomościami rolnymi (Family Farms in the Process of Trade in Agricultural Real Estates). In: Prawne mechanizmy wspierania i ochrony rolnictwa rodzinnego w Polsce i innych państwach Unii Europejskiej (Legal Framework of Support and 
Protection of Family Farms in Poland and other EU countries). Litwiniuk P. (red.). FAPA, Warszawa, 175189.

Marciniuk, K. (2016). Pojecie własności rolnej w kontekście regulacji dotyczacych kształtowania ustroju rolnego (Agricultural Ownership in the Light of Regulations on Agricultural System). In: Kwestia agrarna. Zagadnienia prawne i ekonomiczne (Agrarian Problems. Legal and Economic Issues). Litwiniuk P. (red.). FAPA, Warszawa, 111-125.

Marks-Bielska, R. (2010). Rynek ziemi rolniczej w Polsce - uwarunkowania i tendencje rozwoju (The Market of Agricultural Land in Poland - Conditions and Development Trends). Wydawnictwo Uniwersytetu Warmińsko-Mazurskiego w Olsztynie, Olsztyn.

Marks-Bielska, R. (2016). Czynniki kształtujące obrót gruntami rolnymi w Polsce (Factors Shaping Trade in Agricultural Land in Poland). Świat Nieruchomości 97, 23-29.

Marks-Bielska, R., Kisiel, R. (red.) (2013). Rola Agencji Nieruchomości Rolnych w unowocześnianiu rolnictwa i obszarów wiejskich (Role of the Agricultural Property Agency in Modernization of Agriculture and Rural Areas). Wydawnictwo Uniwersytetu Warmińsko-Mazurskiego w Olsztynie, Olsztyn.

Mikołajczyk, J. (2016). Obrót nieruchomościami rolnymi w świetle ostatnich zmian wprowadzonych ustawą z dnia 14 kwietnia 2016 roku - wybrane zagadnienia (Trade of Agricultural Real Estate in the Light of Recent Changes Implemented by the act of 14 april 2016 - Selected Issues). Acta Universitatis Lodziensis. Folia Juridica 77, 123-136.

Ministerstwo Sprawiedliwości. Akty notarialne w latach 1991-2017 (Ministry of Justice. Notarial Deeds in 19912017). (https://isws.ms.gov.pl/pl/baza-statystyczna/opracowania-wieloletnie/).

Nowak, M., Skotarczak, T. (red.) (2013). Podstawy gospodarowania nieruchomościami (Basics of Real Estate Management). CeDeWu, Warszawa.

Ochrona Środowiska 2016 (Environment 2016). Główny Urząd Statystyczny, Warszawa.

Rynek ziemi rolniczej. Stan i perspektywy (Agricultural Land Market. Situtation and Outlook). IERiGŻ, Warszawa 2011

Rynek ziemi rolniczej. Stan i perspektywy (Agricultural Land Market. Situtation and Outlook). IERiGŻ, Warszawa 2012

Rynek ziemi rolniczej. Stan i perspektywy (Agricultural Land Market. Situtation and Outlook). IERiGŻ, Warszawa 2014.

Rynek ziemi rolniczej. Stan i perspektywy (Agricultural Land Market. Situtation and Outlook). IERiGŻ, Warszawa 2015

Rynek ziemi rolniczej. Stan i perspektywy (Agricultural Land Market. Situtation and Outlook). IERiGŻ, Warszawa 2016.

Rynek ziemi rolniczej. Stan i perspektywy (Agricultural Land Market. Situtation and Outlook). IERiGŻ, Warszawa 2017.

Skoczylas, J.J. (2004). Cywilnoprawny obrót nieruchomościami przez cudzoziemców po wejściu Polski do Unii Europejskiej (Legal Trade in Real Estates for Foreigners After the Accession of Poland to the EU). LexisNexis, Warszawa.

Strzelczyk, R. (2010). Prawo obrotu nieruchomościami (Real Estate Law). Wydawnictwo C.H. Beck, Warszawa.

Szymczyk, P. (2017). Nabywanie nieruchomości rolnych w świetle nowelizacji przepisów o kształtowaniu ustroju rolnego cz. I (Purchase of Agricultural Real Estates in the Light of the Regulations on Shaping of Agricultural System). Nieruchomości 3, 8-13.

Ustawa z dnia 23 kwietnia 1964 roku Kodeks cywilny (Act of 23 April 1964 - Civil Code) (t.j. Dz. U. z 2016 r., poz. 1025).

Ustawa z dnia 27 marca 2007 roku o planowaniu i zagospodarowaniu przestrzennym (Act of 27 March 2007 on spatial planning and development) (t.j. Dz. U. z 2017 r., poz. 1073)

Ustawa z dnia 11 kwietnia 2003 roku o kształtowaniu ustroju rolnego (Act of 11 April 2003 on the shaping of agricultural system) (t.j. Dz. U. z 2018 r., poz. 1405).

Ustawa z dnia 14 kwietnia 2016 roku o wstrzymaniu sprzedaży nieruchomości Zasobu Własności Rolnej Skarbu Państwa oraz zmianie niektórych ustaw (Act of 14 April 2016 on suspension of sale of real property in the Agricultural Property Stock of the State Treasury and on amendment to some statues (Dz. U. z 2016 r., poz. 565 ze zm.).

For citation:

Klusek T. (2018). Out-of-Market Agricultural Property Trading in Poland. Problems of World Agriculture, 18(4), 259-269; DOI: 10.22630/PRS.2018.18.4.116 